\title{
Millennials in the Workplace: A Conceptual Analysis of Millennials' Leadership and Followership Styles
}

\author{
Shih Yung Chou (Corresponding author) \\ HEB School of Business and Administration, University of the Incarnate Word \\ 4301 Broadway, CPO 394, San Antonio, Texas 78209, USA \\ Tel: 1-210-283-6482Ｅ-mail: chou@uiwtx.edu
}

Accepted: March 29, 2012 Published: May 27, 2012

Doi:10.5296/ijhrs.v2i2.1568

URL: http://dx.doi.org/10.5296/ijhrs.v2i2.1568

\begin{abstract}
The Millennial Generation in the workplace has received increasing attention as it has been shown that Millennials demonstrate different attitudes, values, beliefs, and aspirations in the workplace compared to the previous generations. Although a number of studies have devoted to the investigation of Millennials, the leadership and followership styles exhibited by Millennials at work has been largely neglected. Thus, the major purpose of this article is to develop a conceptual framework that explores Millennials' leadership and followership styles in the workplace. By examining Millennials in the context of leadership and followership, this article provides important theoretical and practical implications.
\end{abstract}

Keywords: Millennials, Leadership, Followership

\section{Introduction}

With their entry to the workforce, the Millennial Generation has received increasing scholarly attention (Harris-Boundy \& Flatt, 2010). According to Smola and Sutton (2002), Millennials are those born between 1979 and 1994 and have labeled the Millennial Generation as Generation Y, Nexters, and the Nexus Generation (e.g., Barnard, Cosgrove, \& Welsh, 1998; Burke \& Ng, 2006; Zemke, Raines, \& Filipczak, 2000). Meanwhile, this article uses "Millennials" to describe this generation in order to be consistent with the literature and public press. Despite their popularity in the literature and public press, Millennials have received much concern and speculation. For instance, it is argued that Millennials are self-important, impatient, and disloyal (Hill, 2008; Howe \& Stauss, 2007; Jacobson, 2007). In addition, it is suggested that Millennials are ambitious, value organizational training and 
development, prefer meaningful work, and seek for personal fulfillment on the jobs (Hauw \& Vos, 2010; Loughlin \& Barling, 2001; Rawlins, Indvik, \& Johnson, 2008). Although a number of studies have devoted to the study of Millennials in the workplace, the leadership and followership styles exhibited by Millennials have not received much attention Millenials are not all in the workforce. Therefore, this article strives to address this gap by exploring Millennials' leadership and followership styles in the workplace.

To add crucial knowledge to the analysis of Millennials as leaders and followers, this article evaluates how Millennials' leadership style is shaped by their work attitudes, beliefs, and values and how Millennials behave as followers in the workplace. Specifically, we apply Lewin, Lippitt, and White's (1939) theory of leadership styles, which has been the foci of leadership research and modern management (Deutsch, 1992; Wolf, 1973), and Kelley's (1992) theory of followership as it has been suggested to be one of the most important contributions in the followership literature (Blanchard, Welbourne, Gilmore, \& Bullock, 2009).

The remainder of this article is organized as follows. In the second section, we provide a brief literature review on Millennials in the workplace with the emphasis on their work values, attitudes, and behaviors. Next, we briefly discuss Lewin et al.'s (1939) theory of leadership and Kelley's (1992) theory of followership. This is followed by our theoretical arguments and propositions. In the fourth section, we discuss the implications for theory and managerial practice. The final section concludes this article with a brief summary.

\section{Literature Review}

\subsection{Millennials in the Workplace}

As Millennials are the newest individuals to the workforce, there is an increasing discussion on Millennials in the workplace from various perspectives. For instance, drawing upon an economic model, Barkin, Heerman, Warren, and Rennhoff (2010) analyzed the impact of obesity on lifetime earnings for the Millennial generation and predicted that obese Millennial women and men in the U.S. earn an average of $\$ 956$ billion and $\$ 43$ billion less than non-obese Millennial women and men. In their study of Millennials in teams, Harris-Boundy and Flatt (2010) showed that Millennials demonstrate higher levels of individualism than collectivism. Hershatter and Epstein (2010) explored ways that the Millennial generation approach the world of work and suggested that Millennials integrate technology into their lives and expect accommodations by organizations based upon their experiences, needs, and desires. In their empirical study of the effect of generation on work attitudes, Kowske, Rasch, and Wiley (2010) found that Millennials have higher levels of overall company satisfaction and satisfaction with job security, recognition, and career advancement than Generation Xers and Baby Boomers. Myers and Sadaghiani (2010) discussed Millennials workplace expectations, communication styles, and relationships with team and organizational members. Specifically, these researchers suggested that Millennials work well in team settings, are motivated by significant tasks, prefer open and frequent communication, and comprehend communication technologies. In their field study of the Millennial generation, $\mathrm{Ng}$, Schweitzer, and Lyons (2010) discovered that Millenials emphasize individualism, seek for career 
advancement and skill development, and ensure a meaningful and satisfying life outside of work.

Despite the amount of research on Millennials in the workplace has dramatically increased, two important research areas still need to be addressed. Specifically, with their entry to the workforce, what leadership style do Millennials exhibit? In addition to their leadership style, what is the type of followership style exhibited by the Millennial generation? To answer these questions, I apply the theory of leadership styles developed by Lewin et al. (1939) and the theory of followership developed by Kelley (1992). In the following sections, Lewin et al.'s (1939) theory of leadership and Kelley's (1992) theory of followership are briefly discussed.

\subsection{Lewin's Theory of Leadership Styles}

As the concept of leadership covers a wide range of aspects, it has been defined in various ways. For instance, Fiedler (1967) defined leadership as the individual who is given the task of directing and coordinating task-relevant group activities and who carries the primary responsibility for performing these activities in the group. Stogdill (1974) suggested that leaders initiate and maintain the structure in expectation and interaction. Pfeffer and Salancik (1975) claimed that leadership refers to a leader's task and social behaviors. Bryman (1992) defined leadership as an individual's ability to guide followers toward common goals. Because leadership has been defined in several ways, leadership styles have been developed based upon different dimensions such as decision-making distribution and the relationship between a leader and a follower (Ismail \& Ford, 2010). Among various theories of leadership styles, the study conducted by Lewin and his colleagues is one of the most important and influential social psychological leadership theories (Liden \& Antonakis, 2009; Marrow, 1969; Wolf, 1973). Specifically, Lewin, Lippitt, and White conducted an experimental study in 1939 that examined leadership behavior based on the distribution of decision-making authority between a leader and a follower, and discovered that leadership styles can be described in three patterns: autocratic, participative, and laissez-faire style.

Autocratic leadership occurs when a leader makes decisions without asking for subordinates' opinions and suggestions and therefore subordinates have no influence on the decision-making process (Yukl, 2002). As autocratic leadership style constrains subordinates' inputs in decisions and exhibits little respect for subordinates' opinions and values (Bass, 1990), a number of previous studies have demonstrated the negative outcomes of autocratic leadership style such as negative emotions experienced by subordinates (e.g., De Cremer, 2007), passive-aggressive behavior exhibited by leaders (e.g., Johnson \& Klee, 2007), low satisfaction and motivation demonstrated by subordinates (e.g., De Cremer, 2006), and burnout experienced by subordinates (e.g., De Hoogh \& Hartog, 2009).

Participative leadership style is demonstrated when a leader allows followers to contribute in decision-making process (Kaufman, 2001). Thus, participative leaders consult with subordinates, ask subordinates' suggestions, and take subordinates' ideas into consideration when making decisions (Chen \& Tjosvold, 2006). Given the joint influence on decision making, previous studies have shown various positive outcomes of the participative leadership style such as increased subordinates' motivation (e.g., Locke \& Latham, 1990), 
commitment (e.g., Yammarino \& Naughton, 1992), satisfaction (e.g., Smylie, Lazarus, \& Brownlee-Conyers, 1996), and reduced turnover (e.g., Spector, 1986).

Laissez-faire leadership describes those leaders who are reluctant to influence or give directions to subordinates and subordinates thus have considerable freedom in deciding their actions (Deluga, 1990). Because laissez-faire leaders avoid exercising leadership functions, they avoid making decisions, hesitate in taking actions, and are absent when needed (Judge \& Piccolo, 2004).

\subsection{Kelley's Theory of Followership}

According to Howell and Costley (2001), followership refers to an interactive role that an individual plays that complements the leadership role, and is as important as the leadership role in determining group and organizational performance. Although leaders would not be existent without followers (Hollander, 1993), followership is still an understudied discipline (Mushonga \& Torrance, 2008) because it is usually associated with negative connotations (Bjugstad, Thach, Thompson, \& Morris, 2006). Meanwhile, Kelley (1992) claimed that followers are those individuals who are courageous and honest, and who cooperate to accomplish goals without competing for leadership or power. Based upon the definition of followership, Kelley further conceptualized followership using two behavioral dimensions: critical thinking and active engagement. Specifically, followers with high levels of critical thinking are independent and critical thinkers, willing to be creative and innovative, and willing to offer criticism regardless of the consequences (Mushonga \& Torrance, 2008). Meanwhile, followers who have high levels of active engagement often take initiatives, assume ownership, and actively participate in performing their jobs (Blanchard et al., 2009). Moreover, high actively engaged followers go above and beyond their job requirements and exert effort to accomplish goals (Kahn, 1990; Rothbard, 2001), which in turn lead to positive outcomes such as increased job satisfaction, organizational commitment, and decreased turnover (Salanova, Lorens, Cifre, Martinez, \& Schaufeli, 2003; Schaufeli \& Bakker, 2004).

Based upon the characteristics of followers who demonstrate different levels of critical thinking and active engagement, Kelley developed a four-quadrant followership model that describes four styles of followership including alienated, conformist, passive, and exemplary followers. According to model, alienated followers are those who have a healthy skepticism of the organization. Conformist followers are those who actively do their tasks and follow orders. Passive followers are those who require constant direction. Exemplary followers are characterized as being independent and innovative, and being able to understand how to work and interact with others in organizations.

The brief review of Lewin et al.'s theory of leadership styles and Kelley's (1992) theory of followership styles has shown the behavioral characteristics of each of the leadership and followership styles exhibits. In the following section, I provide my theoretical arguments and positions on the leadership and followership styles exhibited by Millennials at work.

\section{Theoretical Framework and Propositions}

\subsection{Leadership Style Exhibited by Millennials}


Millennials in the workplace have been discussed and researched by previous studies from two major perspectives. A first research stream focuses on Millennials' work attitudes and values. Although consistent findings have not been shown in the literature, it has generally been demonstrated that Millennials focus much on the social aspect of work such as having friendly coworkers and interesting work environment ( $\mathrm{Ng}$ et al., 2010). Similarly, in their empirical study of medical students' motives, Borges, Manuel, Elam, and Jones (2010) found that Millennials have greater social needs, tighter peer bond, and stronger team orientation than Generation Xers. The focus of social aspect at work, however, does not result in Millennials' lack of effort in the workplace. Specifically, Millennials are found to be hard-working, responsible, team-oriented, and altruistic (Elam, Stratton, \& Gibson, 2007; Gloeckler, 2008). Alsop (2008) supported this view by noting that Millennials' altruistic behavior is mainly influenced by their families and friends. It is also because of their team-oriented mindset, Millennials tend to demonstrate an inclusive management style where immediate feedback is emphasized (Lowe, Levitt, \& Wilson, 2008). Additionally, Millennials have been found to demonstrate higher levels of self-esteem and assertiveness than previous generations (Twenge \& Campbell, 2001) and to be extraordinarily confident of their abilities (Harris-Boundy \& Flatt, 2010). These characteristics have also been found by Trzesniewski and Donnellan (2010). Specifically, Trzesniewski and Donnellan revealed that Millennials tend to have high levels of self-esteem and external locus of control compared to previous generations in a study of high school birth cohort.

A second research stream discusses Millennials' communication style. According to previous research, Millennials not only seek for frequent, positive, and open communication in the workplace constantly but also gather and share information readily (e.g., Gursoy, Maier, \& Chi, 2008; Hill 2002; Howe \& Strauss, 2007; Tapscott, 1998; Marston, 2007; Martin, 2005; Zemke et al., 2000). From this perspective, one can expect that Millennials, as leaders, will utilize a two-way communication approach and emphasize the importance of having reciprocal relationships with subordinates. Meanwhile, the leadership literature has suggested that participative leadership involves including subordinates in decision making, asking for subordinates' suggestions, and discussing organizational issues with subordinates (Chen \& Tjosvold, 2006). Thus, when linking Milllennials' workplace attitudes, beliefs, values, and communication style with leadership styles, it is expected that Millennials will demonstrate high levels of participative leadership style. This suggests the first proposition:

Proposition 1: Millennials will demonstrate high levels of participative leadership style in the workplace.

\subsection{Followership Style Exhibited by Millennials}

When examining the communication style of Millennials, previous studies have found that Millennials expect to communicate with their supervisor openly and frequently (Gursoy et al., 2008; Martin, 2005) and to maintain strong relationships with supervisors (Jokisaari \& Nurmi 2009; Martin 2005). Moreover, Alsop (2008) and Gursoy et al. (2008) suggested that Millennials prefer to work with others as they perceive working in groups is interesting. However, Millennials also expect to express their thoughts, ideas, and opinions and are not 
intimidated by others because of lack of experience and status (Myer \& Sadaghiani, 2010). Furthermore, Millennials often demonstrate high levels of need for achievement, trust in their organizations, and desire for organizational systems that support and develop them (Hershatter \& Epstein, 2010; Howe \& Strauss, 2003; Myer \& Sadaghiani, 2010).

According to Kelley's (1992) followership model, it is suggested that exemplary followers play a crucial role in determining organizational success because they are independent, innovative, and willing to question leadership. In other words, exemplary followers constantly engage in critical and independent thinking (Mushonga \& Torrance, 2008). Given that Millennials prefer to express their thoughts, ideas, and opinions freely and frequently (Myer \& Sadaghiani, 2010), one can expect that Millennials will demonstrate the characteristics of exemplary followership style in the workplace.

Moreover, it is suggested that exemplary followers often engage in questioning their leaders' decisions (Mushonga \& Torrance, 2008). In other words, exemplary followers might not consider their statuses, titles, or experience when disagreeing with their leaders. Furthermore, Bjugsad et al. (2006) claimed that exemplary followers work well with others and are always available to those who interact with them. Given that Millennials perceive working in groups to be interesting (Alsop, 2008; Gursoy et al., 2008), one can expect that Millennials will demonstrate the characteristics of exemplary followership style in the workplace. This argument supports the second proposition:

Proposition 2: Millennials will demonstrate high levels of exemplary followership style in the workplace.

\section{Discussion}

This article has intended to describe the leadership and followership styles exhibited by the Millennial generation in the workplace. The purpose is to provide organizations and managers an understanding of Millennials in the contexts of leadership and followership. Given that this aspect has been largely neglected by previous studies, this article provides several important implications for theory and managerial practice. In the following sections, implications for theory and practice are presented.

\subsection{Implications for Theory}

We believe that the investigation of Millennials' leadership and followership in the workplace extends the prior research on Millennials' in two major ways. First, to our best knowledge, this article is one of the first few studies that extend Lewin et al.'s (1939) leadership style theory to the Millennial generation. Specifically, because Millennials will continue to enter the workforce until around 2022 (Hershatter \& Epstein, 2010), this article provides additional insight into the understanding of Millennials as leaders in the workplace as previous research on Millennials focuses much on their attitudes, values, beliefs, and aspirations in the workplace rather than on how Millennials behave as leaders.

In addition to discussing Millennials' leadership style, this article provides important contribution to the followership literature by adding the newest generation of the workforce 
into the literature. Given that followership is an important but understudied field (Blanchard et al., 2009), this article offers a theoretical basis for future theoretical and empirical followership research.

\subsection{Implications for Practice}

If the propositions offered by this article are validated by future empirical research, the framework could have important practical implications. First, understanding Millennials' leadership style may provide insight into designing a work environment where leadership effectiveness is maximized, which in turn fosters individual, group, and organizational performance. For instance, we have claimed that Millennials will demonstrate a participative leadership style in the workplace. Thus, organizations can facilitate leadership effectiveness by removing organizational barriers such as organizational structure and levels as they have been suggested that organizational levels is one of the factors that influence leadership style (Mintzberg, 1980; Yukl, 2002).

Second, by understanding the followership style exhibited by Millennials, organizations and managers are able to manage Millennials work performance more effectively. For example, the leader-member exchange (LMX) theory (Dansereau, Graen, \& Haga, 1975) has suggested that leadership effectiveness is the result of the quality of the dyadic relationship between leader and follower and the quality of this relationship is determined by the negotiation between a leader and follower (Graen \& Scandura, 1987; Graen \& Uhl-Bien, 1995). Since the negotiation is initiated by the leader and reciprocated by the follower, organizations and managers need to ensure that Millennial followers perceive the initial contribution from their leaders so that they are able to experience a more satisfying and high quality LMX relationship, which in turn may improve Millennial followers' performance, satisfaction, and work attitudes. Given that Millennials prefer to express their thoughts, ideas, and opinions freely and frequently (Myer \& Sadaghiani, 2010), high quality LMX can be obtained, for example, by using a two-way communication approach such as offering open forum discussions.

In addition to ensuring the quality of the leader-member relationship, organizations and managers can improve leadership effectiveness by matching right leadership style to Millennials' followership style. Specifically, it is suggested that a leader's effectiveness is greatly influenced by the followers' permission (DePree, 1992). Because Millennials tend to demonstrate high levels of self-esteem and assertiveness and to be extraordinarily confident of their abilities (Harris-Boundy \& Flatt, 2010; Twenge \& Campbell, 2001), a delegating leadership style as suggested by Bjugstad et al. (2006) may be used so that Millennial followers are able to experience high levels of responsibility, work meaningfulness, and personal fulfillment on the jobs, which in turn may lead to high levels of leadership effectiveness and organizational performance.

\section{Limitations and Future Research Suggestions}

By exploring leadership and followership styles exhibited by the Millennial generation at work, this article provides a new perspective on understanding Millennials in the workplace. 
Although this article intends to explore this new perspective, it is not without limitations.

A first limitation is related to the discussion of leadership styles. Specifically, there are many important leadership theories such as the contingency model of leadership (Fiedler, 1967), path-goal theory of leadership (House, 1971; House \& Mitchell, 1974), vertical dyad linkage theory (Dansereau, et al., 1975), transformational leadership theory (Bass, 1985), etc. Although this article applies Lewin et al.'s (1939) theory of leadership styles, which has been a major theoretical base for many studies that investigated different leadership styles (Eagly \& Johannesen-Schmidt, 2001; Rosenbaum \& Rosenbaum, 1971), future research that applies other leadership theories is still needed in order to expand our understanding of Millennials in the context of leadership.

When examining leadership and followership styles of the Millennial generation in the workplace, this article focuses mainly on the attitudes, values, beliefs, and aspirations of Millennials in the workplace identified by previous research. However, it has also been shown that individual and organizational factors could affect leadership and followership styles exhibited. For example, Valliant and Loring (1998) examined the relationship between leadership styles and personality and found that personality traits such as self-control and tolerance significantly affected an individual's leadership style. Moreover, it has been suggested that organizational culture could influence leadership styles in the organization (Lok \& Crawford, 2004; Ogbonna \& Harris, 2000). Although the primary objective of this article is to take the first step and investigate Millennials' leadership and followership styles in the workplace, future studies that include micro- and macro-level variables are still needed to strengthen the framework offered by this article. Despite the potential limitations, this article provides important implications for theory and managerial practice.

\section{Conclusion}

We have sought to explain the leadership and followership styles of the Millennial generation. As this perspective has not been explored by previous studies, this article provides important implications for theory and managerial practice. By understanding Millennials' leadership and followership styles in the workplace, organizations and managers are able to structure a workplace where performance is maximized.

\section{References}

Alsop, R. (2008). The trophy kids grow up. How the Millennial generation is shaping up the workplace. San Francisco, CA: Jossey-Bass.

Barkin, S., Heerman, W., Warren, M., \& Rennhoff, C. (2010). Millennials and the world of work: The impact of obesity on health and productivity. Journal of Business \& Psychology, 25, 239-245.

Bass, B. M. (1985). Leadership beyond expectations. New York: Free Press.

Bass, B. M. (1990). Bass and Stogdill's handbook of leadership: Theory, research, and managerial applications. New York: Free Press. 
Barnard, R., Cosgrove, D., \& Welsh, J. (1998). Chips \& pop: Decoding the nexus generation. Toronto: Malcolm Lester Books.

Bjugstad, K., Thach, E. C., Thompson, K. J., \& Morris, A. (2006). A fresh look at followership: A model for matching followership and leadership style. Journal of Behavioral \& Applied Management, 7, 304-319.

Blanchard, A. L., Welbourne, J., Gilmore, D., \& Bullock, A. (2009). Followership styles and employee attachment to the organization. Psychologist-Manager Journal, 12, 111-131.

Borges, N. J., Manuel, R. S., Elam, C. L., \& Jones, B. J. (2010). Differences in motives between Millennial and Generation X medical students. Medical Education, 44, 570-576.

Bryman, A. (1992). Charisma and leadership in organizations. London: Sage.

Burke, R. J., \& Ng, E. (2006). The changing nature of work and organizations: Implications for human resource management. Human Resource Management Review, 16, 86-94.

Chen, Y. F., \& Tjosvold, D. (2006). Participative leadership by American and Chinese managers in China: The role of relationships. Journal of Management Studies, 43, 1727-1752.

Cheney, G., Christensen, L. T., Zorn, T. E., Jr., \& Ganesh, S. (2004). Organizational communication in an age of globalization: Issues, reflections and practices. Prospect Heights, IL: Waveland Press.

Dansereau, F., Graen, G., \& Haga, W. J. (1975). A vertical dyad linkage approach to leadership within formal organizations: A longitudinal investigation of the role-making process. Organizational Behavior and Human Performance, 13, 46-78.

De Cremer, D. (2006). Affective and motivational consequences of leader self-sacrifice: The moderating effect of autocratic leadership. Leadership Quarterly, 17, 79-93.

De Cremer, D. (2007). Emotional effects of distributive justice as a function of autocratic leader behavior. Journal of Applied Social Psychology, 37, 1385-1404.

De Hoogh, A. H. B., \& Hartog, D. N. D. (2009). Neuroticism and locus of control as moderators of the relationships of charismatic and autocratic leadership with burnout. Journal of Applied Psychology, 94, 1058-1067.

de Vries, R. E., Bakker-Pieper, A., \& Oostenveld, W. (2010). Leadership = communication? The relations of leaders' communication styles with leadership styles, knowledge sharing and leadership outcomes. Journal of Business \& Psychology, 25, 367-380.

Deluga, R. J. (1990). The effects of transformational, transactional, and laissez faire leadership characteristics on subordinate influencing behavior. Basic and Applied Social Psychology, 11, 191-203.

DePree, M. (1992). Leadership jazz. New York: Doubleday Publishing.

Deutsch, M. (1992). Kurt Lewin: The tough-minded and tender-hearted scientist. Journal of Social Issues, 48, 31-43. 
Eagly, A. H., \& Johannesen-Schmidt, M. C. (2001). The leadership styles of women and men. Journal of Social Issues, 57, 781-797.

Elam, C., Stratton, T., \& Gibson, D. (2007). Welcoming a new generation to college: The millennial students. Journal of College Admission, 195, 21-25.

Fiedler, F. E. (1967). A theory of leadership effectiveness. New York: McGraw-Hill.

Gloeckler, G. (2008). Here come the Millennials. Business Week, 4109, 46-50.

Graen, G. B., \& Scandura, T. A. (1987). Toward a psychology of dyadic organizing. Research in Organizational Behavior, 9, 175-208.

Graen, G. B., \& Uhl-Bien, M. (1995). Relationship-based approach to leadership: Development of leader-member exchange (LMX) theory of leadership over 25 years: Applying a multi-level multi-domain perspective. Leadership Quarterly, 6, 219-247.

Gursoy, D., Maier, T. A., \& Chi, C. G. (2008). Generational differences: An examination of work values and generational gaps in the hospitality workforce. International Journal of Hospitality Management, 27, 458-488.

Harris-Boundy, J., \& Flatt, S. J. (2010). Cooperative performance of Millennials in teams. Review of Business Research, 10, 30-46.

Hauw, S., \& Vos, A. (2010). Millennials' career perspective and psychological contract expectations: Does the recession lead to lowered expectations? Journal of Business \& Psychology, 25, 293-302.

Hershatter, A., \& Epstein, M. (2010). Millennials and the world of work: An organization and management perspective. Journal of Business \& Psychology, 25, 211-223.

Hill, L. A. (2008). Where will we find tomorrow's leaders? Harvard Business Review, 23, 123-129.

Hill, R. P. (2002). Managing across generations in the 21st century: Important lessons from the ivory trenches. Journal of Management Inquiry, 11, 60-66.

Hollander, E. P. (1993). Legitimacy, power and influence: A perspective on relational features of leadership. In M. M. Chemers \& R. Ayman (Ed.), Leadership theory and research: Perspectives and directions, (pp. 29-48). San Diego, CA: Academic Press.

House, R. J. (1971). A path-goal theory of leader effectiveness. Administrative Science Quarterly, 16, 334-338.

House, R. J., \& Mitchell, T. R. (1974). Path-goal theory of leadership. Journal of Contemporary Business, 4, 81-97.

Howe, N., \& Strauss, W. (2000). Millennials rising: The next great generation. New York: McGraw-Hill.

Howe, N., \& Strauss, W. (2007). Millennials go to college. Great Falls, VA: LifeCourse 
Associates.

Howell, J. P., \& Costley, D. L. (2001). Understanding behaviors for effective leadership. Upper Saddle River, NJ: Prentice-Hall.

Ismail, K., \& Ford, D. (2010). Organizational leadership in central Asia and the Caucasus: Research considerations and directions. Asia Pacific Journal of Management, 27, 321-340.

Jacobson, W. S. (2007). Two's company, three's a crow, and four's a lot to manage: Supervising in today's intergenerational workplace. Popular Government, 17, 18-23.

Johnson, N. J., \& Klee, T. (2007). Passive-aggressive behavior and leadership styles in organizations. Journal of Leadership \& Organizational Studies, 14, 130-142.

Jokisaari, M., \& Nurmi, J. E. (2009). Change in newcomers' supervisor support and socialization outcomes after organizational entry. Academy of Management Journal, 52, 527-544.

Judge, T. A., \& Piccolo, R. F. (2004). Transformational and transactional leadership: A meta-analytic test of their relative validity. Journal of Applied Psychology, 89, 755-768.

Kahn, W. A. (1990). Psychological conditions of personal engagement and disengagement at work. Academy of Management Journal, 33, 692-724.

Kaufman, B. E. (2001). The theory and practice of strategic HRM and participative management. Human Resources Management Review, 11, 505-533.

Kelley, R. E. (1992). The power of followership. New York: Doubelday.

Kirkpatrick, S. A., \& Locke, E. A. (1996). Direct and indirect effects of three core charismatic leadership components on performance and attitudes. Journal of Applied Psychology, 81, 36-51.

Kowske, B., Rasch, R., \& Wiley, J. (2010). Millennails' (lack of) attitude problem: An empirical examination of generational effects on work attitudes. Journal of Business \& Psychology, 25, 265-279.

Lewin, K., Lippitt, R., \& White, R. K. (1939). Patterns of aggressive behavior in experimentally created social climates. Journal of Social Psychology, 10, 271-299.

Liden, R. C., \& Antonakis, J. (2009). Considering context in psychological leadership research. Human Relations, 62, 1587-1605.

Locke, E. A., \& Latham, P. G. (1990). A theory of goal setting and task performance. Englewood Cliffs, NJ: Prentice-Hall.

Lok, P., \& Crawford, J. (2004). The effect of organizational culture and leadership style on job satisfaction and organizational commitment: A cross-national comparison. Journal of Management Development, 23, 321-338.

Loughlin, C., \& Barling, J. (2001). Young workers' work values, attitudes, and behaviors. 
Journal of Occupational and Organizational Psychology, 74, 543-558.

Lowe, D., Levitt, K., \& Wilson, T. (2008). Solutions for retaining Generation Y employees in the workplace. Business Renaissance Quarterly, 3, 43-57.

Marrow, A. (1969). The practical theorist: The life and work of Kurt Lewin. New York: Basic Books.

Marston, C. (2007). Motivating the "what's in it for me?" workforce: Manage across the generational divide and increase profits. Hoboken, NJ: Wiley.

Martin, C. A. (2005). From high maintenance to high productivity: What managers need to know about Generation Y. Industrial and Commercial Training, 37, 39-44.

Mintzberg, H. (1980). The nature of managerial work. Englewood Cliffs, NJ: Prentice Hall.

Miller, K. (2009). Organizational communication: Approaches and processes. Boston, MA: Wadsworth Cengage Learning.

Mushonga, S. M., \& Torrance, C. G. (2008). Assessing the relationship between followership and the Big Five factor model of personality. Review of Business Research, 8, 185-193.

Myers, K., \& Sadaghiani, K. (2010). Millennials in the workplace: A communication perspective on Millennials' organizational relationships and performance. Journal of Business \& Psychology, 25, 225-238.

Ng, E., Schweitzer, L., \& Lyons, S. (2010). New generation, great expectations: A field study of the Millennial generation. Journal of Business \& Psychology, 25, 281-292.

Ogbonna, E., \& Harris, L. C. (2000). Leadership style, organizational culture and performance: Empirical evidence from UK companies. International Journal of Human Resource Management, 11, 766-788.

Pfeffer, J., \& Salancik, G. R. (1975). Determinants of supervisory behavior: A role set analysis. Human Relations, 28, 139-154.

Rawins, C., Indvik, J., \& John, P. R. (2008). Understanding the new generation: What the Millennial cohort absolutely, positively must have at work. Journal of Organizational Culture, Communications and Conflict, 12, 1-8.

Rosenbaum, L. L., \& Rosenbaum, W. B. (1971). Morale and productivity consequences of group leadership style, stress, and type of task. Journal of Applied Psychology, 55, 343-348.

Rothbard, N. P. (2001). Enriching or depleting? The dynamics of engagement in work and family roles. Administrative Science Quarterly, 46, 655-684.

Salanova, M., Lorens, S., Cifre, E., Martinez, I., \& Schaufeli, W. B. (2003). Perceived collective efficacy, subjective well-being and task performance among electronic work groups: An experimental study. Small Groups Research, 34, 43-73.

Schaufeli, W. B., \& Bakker, A. B. (2004). Job demands, job resources and their relationship 
with burnout and engagement: A multi-sample study. Journal of Organizational Behavior, 25, 293-315.

Smola, K. W., \& Sutton, C. D. (2002). Generational differences: Revisiting generational work values for the new millennium. Journal of Organizational Behavior, 23, 363-382.

Smylie, M. A., Lazarus, V., \& Brownlee-Conyers, J. (1996). Instrumental outcomes of school-based participative decision making. Educational Evaluation and Policy Analysis, 18, 181-191.

Spangler, W. D., \& House, R. J. (1991). Presidential effectiveness and the leadership motive profile. Journal of Personality and Social Psychology, 60, 439-455.

Spector, P. R. (1986). Perceived control by employees: A meta-analysis of studies concerning autonomy and participation at work. Human Relations, 39, 1005-1016.

Stogdill, R. M. (1974). Handbook of leadership: A survey of theory and research. New York: Free Press.

Tapscott, D. (1998). Growing up digital: The rise of the net generation. New York: McGraw-Hill.

Towler, A. J. (2003). Effects of charismatic influence training on attitudes, behavior, and performance. Personnel Psychology, 56, 363-381.

Trzesniewski, K. H., \& Donnellan, M. B. (2010). Rethinking "Generation Me": A study of cohort effects from 1976-2006. Perspectives on Psychological Science, 5, 58-75.

Twenge, J., \& Campbell, W. K. (2001). Age and birth cohort differences in self-esteem: A cross temporal meta-analysis. Personality and Social Psychology Review, 5, 321-344.

Valliant, P. M., \& Loring, J. E. (1998). Leadership style and personality of mock jurors and the effect on sentencing decisions. Social Behavior \& Personality: An International Journal, 26, 421-424.

Wolf, W. B. (1973). The impact of Kurt Lewin on management thought. Academy of Management Proceedings, 322-325.

Yammarino, F. J., \& Naughton, T. J. (1992). Individualized and group-based views of participation in decision making. Group \& Organization Management, 17, 398-413.

Yukl, G. (2002). Leadership in organizations. Englewood Cliffs, NJ: Prentice Hall.

Zemke, R., Raines, C., \& Filipczak, B. (2000). Generations at work: Managing the clash of veterans, boomers, Xers, and nexters in your workplace. New York: AMACOM American Management Association. 